\title{
Treating Effect and Economy Comparison for Three Kinds of Vacuum Preloading Technology
}

\author{
Wenbin Liu 1, 2, 3, 4, a , Ruiqi Zhang 1, 2, 3,4 \\ ${ }^{1}$ Tianjin Port Engineering Institute Co., Ltd. of CCCC First harbor engineering Co., Ltd., Tianjin, \\ 300222, China \\ ${ }^{2}$ Key Laboratory of Port Geotechnical Engineering, Ministry of Communications, PRC, Tianjin, \\ 300222, China \\ ${ }^{3}$ Key Laboratory of Port Geotechnical Engineering of Tianjin, Tianjin, 300222, China \\ ${ }^{4}$ CCCC First Harbor Engineering Company Ltd., Tianjin, 300461, China \\ aliuwenbin3943@163.com
}

Keywords: regular vacuum preloading method; direct vacuum preloading method; pressurized vacuum preloading; soft soil foundation treating

\begin{abstract}
The vacuum preloading technology is used commonly in engineering cases to treat soft soil foundation. In addition to the regular vacuum preloading technology, many kinds of modified vacuum preloading technologies are developed in practice. This paper analyzed the regular vacuum preloading, direct vacuum preloading and pressurized vacuum preloading technology in foundation treating effect based on in-site experiments in different areas in Tianjin Port. The comparison will benefit for other engineering cases in choosing a soft soil foundation treating plan suitable for engineering.
\end{abstract}

\section{Introduction}

The direct vacuum preloading method removes the sand layer used in the regular vacuum preloading method and connects the plastic drain board with the vacuum manifold directly. This development can reduces the energy and vacuum load loss in the sand layer and improves the utilization of vacuum load. The pressurized vacuum preloading method is developed based on the direct vacuum preloading method. It added pressurizing pipe to raise the vacuum load to enhance the soft soil foundation better. Many scholars had studied the performance of the direct vacuum preloading method and pressurized vacuum preloading method [1-4], while the comparison of the three technologies on the technical difference and economic efficiency is rare.

This paper proposes these three different technologies in three test areas which belong to a same reinforcement engineering of dredger filling foundation in Tianjin port.The ground surface settlement and pore water pressure were monitored in the vacuum preloading applying process to evaluate the soil strength enhancing effect of the three technologies. The economic key indexes of the three 
technologies were also recorded for comparison. Therefore the soil strength enhancing effect and economic cost can be both considerate in others engineering cases.

\section{The In-site Experiments}

The in-site experimenting field locates at a soft soil foundation strength enhancing treatment area in Tianjin Port. The ground is formed with dredger filling soil, and the property parameters of the soil are listed in Table 1.

Table 1 Parameter of soil properties

\begin{tabular}{|c|c|c|c|c|c|}
\hline \multirow{2}{*}{ Layers } & \multirow{2}{*}{$\begin{array}{c}\text { Thickness } \\
\mathrm{m}\end{array}$} & \multirow{2}{*}{$\begin{array}{l}\text { Weight } \\
\mathrm{kN} / \mathrm{m}^{3}\end{array}$} & $\begin{array}{c}\text { Sub-weight } \\
\mathrm{kN} / \mathrm{m}^{3}\end{array}$ & \multicolumn{2}{|c|}{ Shearing strength } \\
\cline { 5 - 6 } & & & & & \\
& & & & & \\
Dredger filling soil & 6.1 & 15.9 & & 14.1 & 7.92 \\
\hline Mud & 2.2 & 16.2 & 6.2 & 14.57 & 7.67 \\
\hline Silty clay & 2.7 & 18.5 & 8.5 & 18.93 & 12.13 \\
\hline silt & 7.8 & 19.3 & 9.3 & 5.23 & 28.97 \\
\hline Clay & 6.2 & 18.8 & 8.8 & 20.71 & 10.42 \\
\hline
\end{tabular}

The test filed is divided into three test areas for different vacuum preloading technologies, and Table 2 shows the technical details for vacuum preloading applying in each test area.

Table 2 Technical details for each vacuum preloading technology

\begin{tabular}{|c|c|c|c|c|}
\hline \multicolumn{2}{|c|}{ Test areas NO. } & $1 \#$ & 2\# & 3\# \\
\hline \multicolumn{2}{|c|}{ Technology Category } & Direct & Regular & Pressurized \\
\hline \multicolumn{2}{|c|}{ Sand layer } & None & $\begin{array}{l}0.5 \mathrm{~m} \text { deep; medium sand; } \\
\text { laying on the ground surface }\end{array}$ & None \\
\hline \multicolumn{2}{|c|}{ Vacuum preloading (kPa) } & 85 & 85 & 80 \\
\hline \multicolumn{2}{|c|}{ preloading duration (days) } & 150 & 130 & 150 \\
\hline \multirow{4}{*}{$\begin{array}{l}\text { Plastic drain } \\
\text { board }\end{array}$} & Depth (m) & 18 & 21 & 23.5 \\
\hline & Interval (m) & 1 & 0.7 & 0.8 \\
\hline & Distribution pattern & Square & Square & Square \\
\hline & Type & $\begin{array}{l}\text { Deep standard } \\
\text { board }\end{array}$ & Narrow non-standard board & B-type board \\
\hline \multirow{3}{*}{$\begin{array}{l}\text { Pressurizing } \\
\text { pipe }\end{array}$} & Depth (m) & \multirow{3}{*}{ None } & \multirow{3}{*}{ None } & 5 \\
\hline & Interval (m) & & & 0.8 \\
\hline & Distribution pattern & & & Square \\
\hline
\end{tabular}

The dynamical ground surface settlement and pore water pressure data were immediately tested and recorded in the whole treating process. The in-site vane shear tests were also proposed to test the strength enhancing effect. 


\section{In-site Experiment Data}

\subsection{Ground surface settlement}

The surface settlement includes the settlement in drain board setting period and the settlement in vacuum load applying period. The settlement in drain board setting period is caused by the soil consolidation due to self-weight in drain board setting period. And the settlement in vacuum load applying period is mainly caused by the soil consolidation due to vacuum load. The ground surface settlement of each test area is shown in Table 3.

Table 3 Ground surface settlement of each test area

\begin{tabular}{|c|c|c|c|c|c|}
\hline $\begin{array}{c}\text { Test } \\
\text { areas } \\
\text { NO. }\end{array}$ & $\begin{array}{c}\text { Settlement in drain } \\
\text { board setting period } \\
(\mathrm{mm})\end{array}$ & $\begin{array}{c}\text { Settlement in } \\
\text { vacuum } \\
\text { load applying } \\
\text { period } \\
(\mathrm{mm})\end{array}$ & $\begin{array}{c}\text { Total } \\
\text { settlement } \\
(\mathrm{mm})\end{array}$ & $\begin{array}{c}\text { Settlement } \\
\text { developing } \\
\text { rate } \\
(\mathrm{mm} / \text { day) }\end{array}$ & $\begin{array}{c}\text { Consolidation } \\
\text { degree } \\
(\%)\end{array}$ \\
\hline $1 \#$ & 590 & 1733 & 2323 & 2.3 & 89.23 \\
\hline $2 \#$ & 633 & 1749 & 2383 & 2.4 & 85.01 \\
\hline $3 \#$ & 830 & 1811 & 2641 & 1.7 & 85.22 \\
\hline
\end{tabular}

Figure 1 shows the development of ground settlement in vacuum load applying period. Figure 1 shows that the consolidation degrees of all three test areas are above $85 \%$ after vacuum preloading treatment, and the settlement development rate are all smaller than $2.5 \mathrm{~mm} / \mathrm{d}$. The ground surface settlement of $3 \#$ test area in vacuum load applying period is the largest one in all three areas. The settlement of $2 \#$ test area is relative smaller than $3 \#$ test area and the settlement of $1 \#$ test area is the least in all three areas. But the differences between 3 areas are not large, and the biggest difference is smaller than $4.5 \%$. The ground surface is little affected by the type of vacuum preloading technology.

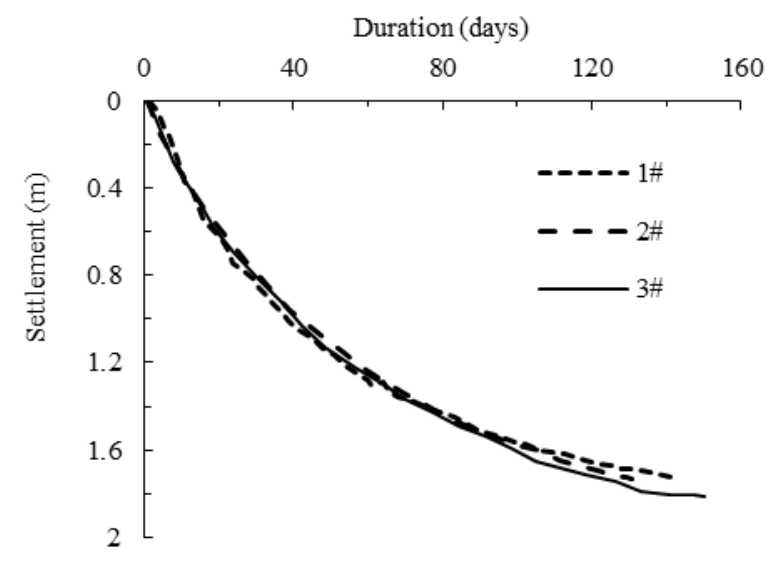

Fig. 1 Ground surface settlement in vacuum load applying period

\subsection{Pore water pressure}

The dissipation of pore water pressure represents the soft soil foundation consolidation and the effective stress development features. The pore water pressure of center position of each test area is monitored in the vacuum load applying period. Each monitoring point contains 6 monitors separating at 6 different depths, and the depth interval between adjacent 2 monitors is $3 \mathrm{~m}$. Therefore, the pore 
water dissipation and soil consolidation of soil in different depth can be monitored. Figure 2 shows the relationship between pore water pressure dissipation value and depth for the three test areas.

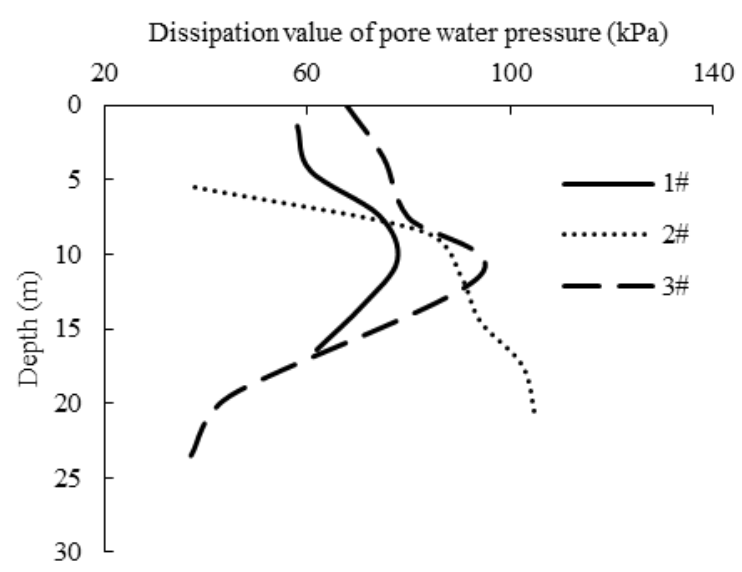

Fig. 2 Dissipation value of pore water pressure in different depth

Figure 2 shows that the maximum dissipation value for $1 \#$ and $3 \#$ test area locates at the middle of drain board and the dissipation value of upper layer and lower layer are relative smaller. The maximum dissipation value for $2 \#$ test area locates at the endpoint of drain board, and the dissipation value decreases with the depth deceasing. It reveals that the regular vacuum preloading technology has better treatment effect in treating deep soil. The maximum pore water dissipation value for $3 \#$ test area is $20 \%$ bigger than $2 \#$ test area, and this shows that the pressuring technology can effectively increases the dissipation value.

\subsection{Shearing strength}

The in-site vane shearing tests were carried out in test areas, and the shearing strength after vacuum preloading treatment is shown in Figure 3.

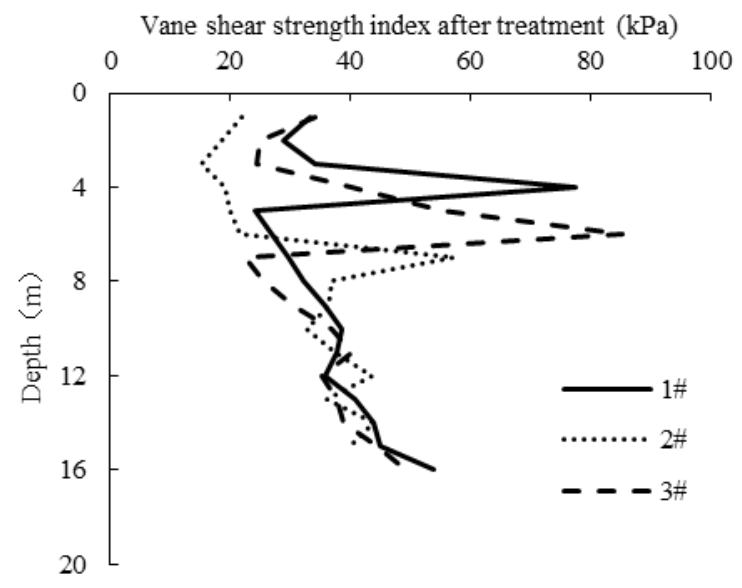

Fig.3 Vane shear strength in different depth

Figure 3 shows that the shearing strength of all three areas increase after vacuum preloading treatment, but the increment on strength is different from depth to depth. The direct vacuum preloading technology has the best effect on treating the shallow layer (depth $<4 \mathrm{~m}$ ), then comes pressurized vacuum preloading technology. The regular vacuum preloading technology has the worst effect on treating the shallow layer. The maximum increments on shearing strength for all three technologies exist at a little deeper layer. The corresponding depth of best treating effect for regular 
vacuum preloading, direct vacuum preloading and pressurized vacuum preloading technology are 7 $\mathrm{m}, 4 \mathrm{~m}$ and $6 \mathrm{~m}$. For much deeper layer (depth $>10 \mathrm{~m}$ ), the treating effect of three kinds of technologies are almost same.

\section{Conclusions}

This paper analyzed three different kinds of vacuum technologies, and proposes a comparison of foundation treating effect. The main conclusions are as follow.

(1) The ground settlement of regular vacuum preloading, direct vacuum preloading and pressurized vacuum preloading are almost the same. The largest difference of settlement is within $4.5 \%$.

(2) The three kinds of vacuum preloading technologies can make the pore water pressure dissipate quickly. The regular can signally reduce the pore water pressure in deep soil layer. The direct and pressurized vacuum preloading can reduce the pore water pressure in middle soil layer well. The pore water dissipation value of pressurized vacuum preloading technology is $20 \%$ higher than direct vacuum preloading technology.

(3) The three kinds of vacuum preloading technologies can enhance soil shearing strength, but the treating area and effect is different. For shallow soil layer the direct vacuum preloading technology is best, and then comes the pressurized vacuum preloading technology. The regular vacuum preloading technology is worst. For deep soil layer, the treating effect of three technologies is almost the same.

\section{References}

[1] Xia Yubin, Chen Jian, Chen Yunjin. Effect and economic analysis of direct vacuum preloading method for consolidation of soft ground [J]. Port Waterway Engineering, 2011(9):224-229.

[2] Chen Yunjin, Xia Yubin, Liu Jian. Laboratory model test of reinforcing heavy clay recently reclaimed soil by straight-line vacuum preloading [J]. Port \& Waterway Engineering, 2011 (10):125-131.

[3] Liu Hao, Yu Xuepeng, Cui Junjie,Liang Yingjun. Comparative Experiment Study on the Strengthening of Dredger Fill Using Vacuum Preloading Method Based on Pressurization and Anti-clogging Technology [J]. Railway Standard Design, 2014, 58(1):28-33.

[4] Ding Hailong, Guo Zhipeng, Fan Kaiyi. Comparative Experiment on Soft Soil Treatment by Air-boosted Vacuum Preloading [J]. Chinese Journal of Underground Space and Engineering, 2015, 11(1):16-18. 